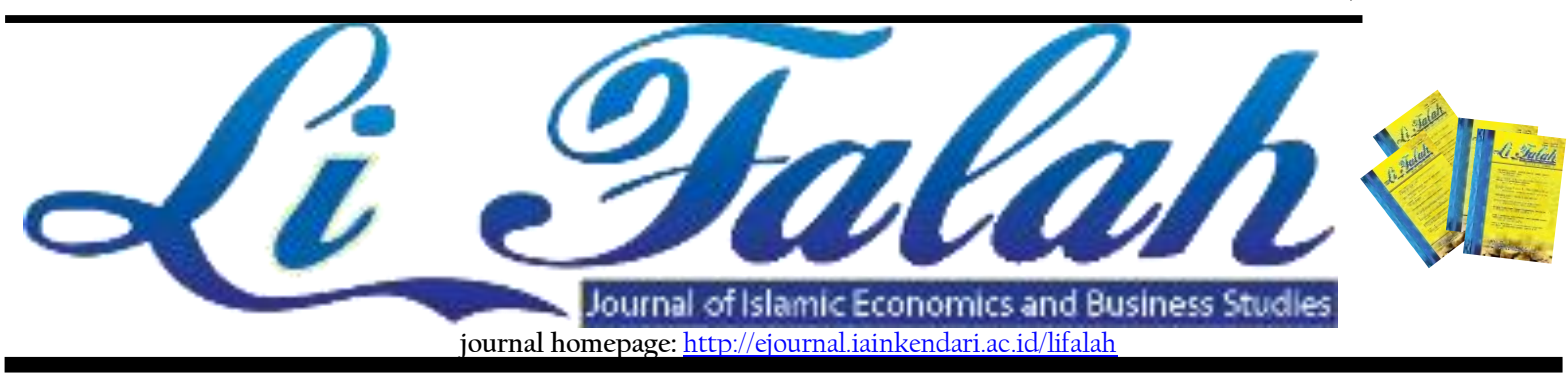

\title{
Measurement of the Zakat Village Index in Curug Depok
}

\author{
Widya Putri ${ }^{1}$, Efri Syamsul Bahri², Prayogo P. Harto ${ }^{3}$ \\ 1, 2, 3Sekolah Tinggi Ekonomi Islam SEBI (STEI SEBI), Indonesia \\ e-cmail: *lwidyaputri.071097@gmail.com, ${ }^{2} e f r i . s b @ s e b i . a c . i d,{ }^{3}$ prayogo.p.harto@gmail.com
}

\begin{tabular}{|c|c|}
\hline ARTICLE INFO & A B S T R A C T \\
\hline $\begin{array}{l}\text { Article History: } \\
\text { Received } 27 \text { March } 2021 \\
1^{\text {st }} \text { Received in revised form } 12 \text { May } \\
2021 \\
2^{\text {nd }} \text { Received in revised form } 7 \text { August } \\
2021 \\
3^{\text {rd }} \text { Received in revised form } 23 \\
\text { September } 2021 \\
\text { Available online } 30 \text { December } 2021\end{array}$ & $\begin{array}{l}\text { Zakat funds are a mandate of Allah SWT that must } \\
\text { be distributed to mustahiq. This study aims to } \\
\text { measure the feasibility of a village to be assisted by } \\
\text { using zakat funds. The method used is a qualitative } \\
\text { method using the Village Zakat Index (IDZ) } \\
\text { model. The IDZ measurement includes five } \\
\text { dimensions: economy, health, education, humanity, } \\
\text { and dakwah. The research was conducted at Curug } \\
\text { Depok. Data collection techniques were carried out } \\
\text { through interviews, questionnaires, and expert } \\
\text { judgment consisting of village officials, RT, and the } \\
\text { community. The results showed that the IDZ value } \\
\text { in Curug was categorized as functional with a score } \\
\text { of } 0.79 \text {. This finding indicates that Cukug is not } \\
\text { prioritized to be assisted by zakat funds. The } \\
\text { dimensions with the lowest IDZ value are the } \\
\text { economic and human dimensions of } 0.61 \text { and } 0.78 \text {. } \\
\text { This data shows that zakat institutions can } \\
\text { implement empowerment programs focusing on } \\
\text { economic and humanitarian programs. }\end{array}$ \\
\hline
\end{tabular}

\section{Introduction}

To optimize the achievement of zakat management goals, namely, increasing the benefits of zakat to realize social welfare and poverty alleviation, the National Zakat Agency (Baznas) utilizes zakat through the Community Development Zakat program (ZCD). The empowerment program was implemented by the West Nusa Tenggara Province Baznas (Lailatussufiani et al., 2016). According to Ismail et al. (2018), the main principle of zakat utilization is that everything must be distributed to those entitled to receive it (mustahiq), as described in QS At-Taubah 60.

Ismail et al. (2018) explain that to carry out the utilization of zakat; there are several criteria must be met, including (1) fulfilling the provisions of Sharia, (2) producing added economic value for mustahiq, (3) mustahiq domiciled in the work area of a zakat management institution. (4) beneficiaries are individuals or groups who meet the mustahiq criteria, and (5) 
provide guidance or assistance to mustahiq from amil zakat who are in the mustahiq domicile area.

Zalikha (2016) states that zakat utilization programs must run effectively and on the target. Therefore, Jamilah (2017) and Triyani et al. (2018) argue that efforts are needed to reduce the risk of failure. One way to reduce risk is to measure the utilization program starting at the pre-, during, and post-program phases. This measurement is essential to ensure that the funds of the people entrusted with it positively impact mustahiq (Puskas, 2017a). In addition, this measurement explains that zakat has good governance (Ahmed, 2008; Lenap et al., 2020). One of the measurement models developed by the Center for Strategic Studies Baznas is the village zakat index (IDZ) (Puskas, 2017b).

Nurzaman and Annisa (2017) first conducted research using the IDZ model in three villages: Secanggang village and Selontong village in Langkat Regency and Buring Village in Malang. The IDZ score is categorized as quite good on a scale of values 0.41-0.60. This data shows that the three points can be considered for assistance with zakat funds. The subsequent IDZ measurement in 2018 with a location in Sungai Dua Village, Rambutan District by Jamil (2018) with an IDZ value of 0.65, with a good or not prioritized category for assistance with zakat funds, in Bendono Village, Demak Regency with an IDZ value of 0.49 and can be considered for assistance with funds zakat (Novianti and Ali, 2018).

Other research conducted by Maulida and Rahmatullah (2018) in the area of the Zakat Community Development (ZCD) program in Beruntung Jaya Village, South Kalimantan, with a value of 0.48 and can be prioritized for assistance with the Zakat Fund as well as research by Beik and Sartono (2019) in Cemplang Village Bogor Regency with an IDZ value of 0.58 , including eligibility for assistance by the zakat fund. Another study conducted by Hakim et al. (2019) in Binangun Village, Pataruman District, Banjar City, with an IDZ value of 0.56 , can be prioritized in the pretty good category for assistance zakat funds.

Of all the previous studies, no research has been conducted in Depok City, especially in Kelurahan Curug, Bojongsari District. Research on IDZ in Depok City is essential because there are also Zakat management institutions in Depok, namely, the National Board of Zakat (Baznas) Depok City and the Successful Amil Zakat Institution (LAZ), which is the LAZ at the city level. The IDZ research hopes to contribute to Zakat management institutions in Depok City so that zakat's utilization can be carried out effectively and on the target.

Based on the description above, this research aims to measure the Zakat Village Index in Curug Depok. Thus, the title of this research is A Measurement of the Zakat Village Index in Curug Depok.

\section{Literature Review}

\section{Utilization of Zakat}

Ahmed (2004) explains, according to Faris (1998), zakat refers to growth, improvement, cleanliness, and purity in Arabic. The position of zakat is mandatory for Muslims (Ahmed, 2004), one of the pillars of Islam (Oktaviani and Bahri, 2018; Rais, 2009), and has a strategic function in improving welfare (Bahri et al., 2019; Kasri, 2016; Ismail et al., 2018), and become an instrument of economists and interest of the community (S, 2016). Even zakat plays an essential role in maintaining social harmony between the rich and the poor (Akbarizan et al., 2016), a means of creating social justice (Sarif and Kamri, 2009), acting as a stabilizer in the economic cycle (Daly and Frikha, 2015). 
According to the terminology of fiqh, zakat is the issuance of part of the assets that are channeled to those entitled to receive it so that the assets that remain are clean and those who obtain it become pure in spirit and behavior (Fahruddin, 1992); (Ladiku, 2020). This definition is in harmony with that described in The Fiqh Encyclopedia (1992) and Ahmed (2004) that in Fiqh Zakat is defined as the right to specific items of assets/property, in a certain percentage with the consideration of a year's trip and the satisfaction of the nisab conditions.

Bahri and Khumaini (2020) describe, according to Abdus Sami (2010), the zakat fund is distributed to eight asnaf according to the Alquran letter At-Taubah verse 60, which consists of Fakir, Miskin, Amil, Muallaf, Riqob, Ghorimin, Ibnu sabil, and Fii sabilillah. One of the models of zakat distribution is through utilization programs. According to BAZNAS Regulation No.3 of 2018 concerning distribution and utilization (Bahri and Khumaini, 2020), zakat is used in the form of a productive business to alleviate poverty (Widiastuti and Rosyidi, 2015).

\section{Zakat Village Index}

The Zakat Village Index (IDZ) is a model for measuring a village's condition to assess whether it is feasible or not feasible to be assisted by the zakat fund. The Zakat Village Index is a reference for the zakat management organization (OPZ), both of which will implement village or community-based empowerment programs (Puskas, 2017b). 
Table 1. Components of the Zakat Village Index

\begin{tabular}{|c|c|c|}
\hline Dimension & Variable & Indicator \\
\hline \multirow[t]{13}{*}{ Economy } & Productive & 1. Having diversification of superior products/production centers \\
\hline & Economic Activities & (defined) \\
\hline & & 2. Labour force participation rate \\
\hline & & 3. There is a community of creative Industry activists \\
\hline & $\begin{array}{l}\text { Village Trade } \\
\text { Center }\end{array}$ & $\begin{array}{l}\text { 1. There is a market as a means of trading and a provider of } \\
\text { community needs, both traditional and online (online } \\
\text { marketing) }\end{array}$ \\
\hline & & $\begin{array}{l}\text { 2. There is a place to trade (shopping complex, minimarket, } \\
\text { warung, hawker center / Pujasera / Culinary Center) }\end{array}$ \\
\hline & Access to & 1. Accessibility of village roads \\
\hline & Transportation And & 2. There are modes of public transportation \\
\hline & $\begin{array}{l}\text { Logistics/Delivery } \\
\text { Services }\end{array}$ & 3. There are logistic services/delivery of goods \\
\hline & Access to Financial & 1. Availability and accessibility of institutions \\
\hline & Institutions & 2. Sharia and conventional finance \\
\hline & & 3. Community involvement with moneylenders \\
\hline & & 4. The level of service users of financial institutions \\
\hline \multirow[t]{8}{*}{ Health } & Public Health & $\begin{array}{l}\text { 1. Availability of clean water facilities for bathing and washing in } \\
\text { each house }\end{array}$ \\
\hline & & 2. Availability of bathroom and restroom facilities in the house \\
\hline & & 3. Source of drinking water \\
\hline & Health Services & 1. Puskesmas/Poskesdes facilities are available \\
\hline & & 2. Poland's facilities are available \\
\hline & & 3. Posyandu facilities are available \\
\hline & & 4. Availability of certified doctors/midwives \\
\hline & Health Insurance & - $\quad$ The level of BPJS participation in the community \\
\hline \multirow[t]{5}{*}{ Education } & Education and & 1. The level of education of the villagers \\
\hline & Literacy Levels & 2. People can read and count \\
\hline & Educational & 1. There are learning facilities and infrastructure \\
\hline & Facilities & 2. Access to schools is affordable and easy \\
\hline & & 3. Availability of an adequate number of teachers \\
\hline \multirow[t]{8}{*}{ Humanity } & Facilities for Open & 1. Availability of sports facilities \\
\hline & Community & 2. There is a community activity group (village consultative body, \\
\hline & Interaction & recitation, youth organization, and arisan) \\
\hline & Electricity, & 1. Availability of electricity \\
\hline & Communication, & 2. There is communication access (handphone) \\
\hline & and Information & 3. There is internet access \\
\hline & Infrastructure & 4. There is a television or radio broadcast \\
\hline & $\begin{array}{l}\text { Natural Disaster } \\
\text { Mitigation }\end{array}$ & - $\quad$ Disaster management \\
\hline \multirow[t]{9}{*}{ Dakwah } & Availability of & The availability of mosques in the community \\
\hline & Facilities \& & 2. Access to the Mosque. \\
\hline & Religious Assistance & 3. There is a religious companion (ustadz/ustadzah) \\
\hline & Level of Public & 1. The level of literacy of the community's Koran \\
\hline & Religion Knowledge & $\begin{array}{l}\text { 2. Community awareness for zakat and infaq (sharing with fellow } \\
\text { humans) }\end{array}$ \\
\hline & Level of Religious & 1. The implementation of routine religious activities \\
\hline & Activity and & 2. The level of community participation for prayer five times in \\
\hline & Community & congregation \\
\hline & Participation & $\begin{array}{l}\text { 3. Level of community participation in routine religious activities } \\
\text { (weekly or monthly recitation) }\end{array}$ \\
\hline
\end{tabular}




\section{Research Method}

This study used qualitative and quantitative methods using a descriptive approach. The type of data used consisted of primary and secondary data. Preliminary data were obtained from interviews, observations, and questionnaires. Furthermore, secondary data from books, documents/ financial reports, journals, and other relevant literature were obtained. The study was conducted in Kelurahan Curug, Bojongsari District, Depok, West Java Province, from August to October 2019.

Measuring village conditions using the village zakat index model. The IDZ measurement is carried out in stages by calculating the value of the zakat index components, namely: indicators, variables, and the five dimensions of the IDZ (economy, health, education, humanity, and dakwah. The village zakat index values ranged from 0 to 1 . The more the IDZ value approaches 1 , the village is not prioritized for assistance. Conversely, the more IDZ comes 0 , the more priority the village is for service. The IDZ measurements were divided into five score ranges and categories, as described in the table below.

Table 2. Score Range of Zakat Village Index

\begin{tabular}{c|c|l}
\hline Score Range & Category & \multicolumn{1}{|c}{ Interpretation } \\
\hline $0,00-0,20$ & Very low & Highly prioritized for assistance \\
\hline $0,21-0,40$ & Low & Prioritized for assistance \\
\hline $0,41-0,60$ & Medium & Can be considered for assistance \\
\hline $0,61-0,80$ & Good & Less priority for assistance \\
\hline $0,81-1,00$ & Excellent & Not prioritized for assistance \\
\hline
\end{tabular}

Source: Puskas (2017b)

IDZ measurements were carried out in four stages. First, each indicator has assessment criteria or a Likert scale, consisting of five assessment criteria, so that the calculation results start from the smallest number 1 to the most significant 5 . After obtaining the actual number, the indicator is calculated as follows:

Where:

$$
\text { Indicator } x=\frac{(\text { Score } x-\text { Score } \min )}{(\text { Score } \max -\text { Skore } \min )}
$$

Indicator $\mathrm{x}=$ indicator value $\mathrm{x}$

Score $\mathrm{x}=$ score on indicator $\mathrm{x}$

Score $\max =5$ (greatest value)

Score $\min =1$ (smallest value)

Second, after each indicator's value is obtained, it is multiplied by each indicator's weight to obtain the indicator index. Third, the indicator index is grouped according to the variables multiplied by each variable's weight to get the variable index. Fourth, each variable's index is multiplied by the weight of each dimension to obtain the dimension index. The result is a composite index called the Zakat Village Index, with the following formula: 


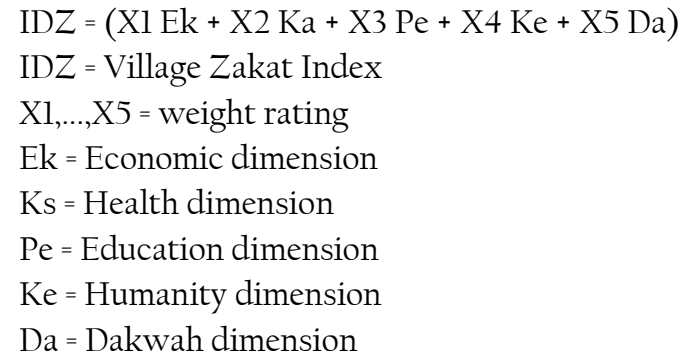

\section{Result and Discussion}

\section{Profile of Kelurahan Curug}

The Curug is Kelurahan in the Bojongsari District, Depok City, West Java Province. The Curug covers \pm 439 ha, most used for housing. The total population of this Kelurahan is 22,817 people, with a population density of $4,474 / \mathrm{km} 2$. Meanwhile, the majority of the main types of work are private employees. In Kelurahan Curug, the SEBI School of Islamic Economics was established in 2010.

\section{IDZ Calculation}

IDZ measurements were carried out on five dimensions: economy, health, education, humanity, and dakwah. The measurement results show that the IDZ value is above the average (0.50-1) or in the five dimensions' good and excellent categories. The IDZ measurement results are shown in the table below.

Tabel 3. IDZ Dimension Index Value for Kelurahan Curug

\begin{tabular}{lc}
\hline Dimension & Index Value \\
\hline Economy & 0.61 \\
\hline Health & 0.91 \\
\hline Education & 0.88 \\
\hline Humanity & 0.78 \\
\hline Dakwah & 0.83 \\
\hline \multicolumn{2}{c}{ Source: Primary data (2019), processed. }
\end{tabular}

Based on the table above, the IDZ measurement results obtained a value of 0.79 in the Good category. Thus, Zakat distribution is one of the least prioritized. The measurements of the five IDZ dimensions were as follows:

$$
\begin{aligned}
& I D Z=0.25 X 1+0.16 \times 2+0.20 \times 3+0.17 X 4+0.22 \times 5 \\
& I D Z=0.25(0.61)+0.16(0.91)+0.20(0.88)+0.17(0.78)+0.22(0.83) \\
& I D Z=0.79
\end{aligned}
$$

Furthermore, each dimension in the IDZ measurement is described below.

\section{Economic Dimension}

The economic dimension is the most significant contributor to the weight in determining the IDZ, which is 0.25 . This data is because the economic extent is the first yardstick to assess the condition of mustahiq. The variable index and indicators in the economic dimension are as follows from calculations that have been made. 
Table 4. Value of Economic Variable Index for Kelurahan Curug

\begin{tabular}{|c|c|c|c|}
\hline Variable & $\begin{array}{l}\text { Value } \\
\text { Variable }\end{array}$ & Indicator & $\begin{array}{l}\text { Value } \\
\text { Indikator }\end{array}$ \\
\hline \multirow[t]{3}{*}{$\begin{array}{l}\text { Productive Economic } \\
\text { Activities }\end{array}$} & \multirow{3}{*}{0.67} & $\begin{array}{l}\text { Having diversification of superior } \\
\text { products/production centers (defined) }\end{array}$ & 0.25 \\
\hline & & Labour force participation rate & 0.75 \\
\hline & & There is a community of creative Industry activists & 1 \\
\hline \multirow[t]{2}{*}{ Village Trade Center } & \multirow{2}{*}{0.47} & $\begin{array}{l}\text { There is a market as a means of trading and a } \\
\text { provider of community needs, both traditional and } \\
\text { online (online marketing) }\end{array}$ & 0 \\
\hline & & $\begin{array}{l}\text { There is a place to trade (shopping complex, } \\
\text { minimarket, warung, hawker } \\
\text { center/Pujasera/Culinary Center) }\end{array}$ & 1 \\
\hline \multirow{3}{*}{$\begin{array}{l}\text { Access to } \\
\text { Transportation and } \\
\text { Logistics/Delivery } \\
\text { Services }\end{array}$} & \multirow{3}{*}{0.76} & Accessibility of village roads & 1 \\
\hline & & There are modes of public transportation & 0.25 \\
\hline & & There are logistic services/delivery of goods & 1 \\
\hline \multirow[t]{3}{*}{$\begin{array}{l}\text { Access to Financial } \\
\text { Institutions }\end{array}$} & \multirow{3}{*}{0.57} & $\begin{array}{l}\text { Availability and accessibility of institutions Sharia } \\
\text { and conventional finance }\end{array}$ & 0.25 \\
\hline & & Community involvement with moneylenders & 0.75 \\
\hline & & The level of service users of financial institutions & 0.75 \\
\hline
\end{tabular}

Source: Primary data (2019) proceed.

The formula used to measure these dimensions is the following formula:

$\mathrm{IDZ}=0.28(\mathrm{Xl})+0.24(\mathrm{X} 2)+0.22(\mathrm{X} 3)+0.26(\mathrm{X} 4)$

$\mathrm{IDZ}=0.28(0,67)+0.24(0,47)+0.22(0,76)+0.26(0,57)$

IDZ $=0,61$

The economic dimension index value is 0.61 in the Good category, so it is less considered for Zakat Fund assistance. The natural potential is cassava plantations, ornamental fish, and star fruit. Its superior products are processed home products such as dodol, cireng, and ornamental plants.

\section{Health Dimension}

The health dimension value portion is 0.16 , or the most diminutive dimensions measured in the IDZ calculation.

Tabel 5. Nilai Indeks Variabel Kesehatan Kelurahan Curug

\begin{tabular}{|c|c|c|c|}
\hline Variable & $\begin{array}{l}\text { Value } \\
\text { Variable }\end{array}$ & Indicator & $\begin{array}{l}\text { Value } \\
\text { Indicator }\end{array}$ \\
\hline \multirow[t]{3}{*}{ Public health } & \multirow[t]{3}{*}{1.00} & $\begin{array}{l}\text { Availability of clean water facilities for bathing and } \\
\text { washing in every house }\end{array}$ & 1 \\
\hline & & $\begin{array}{l}\text { Availability of bathroom and toilet facilities in the } \\
\text { house }\end{array}$ & 1 \\
\hline & & Source of drinking water & 1 \\
\hline \multirow[t]{4}{*}{ Health services } & \multirow[t]{4}{*}{0.75} & There are Puskesmas/Poskesdes facilities available & 0.25 \\
\hline & & Policies facilities are available & 0.75 \\
\hline & & Posyandu facilities are available & 1 \\
\hline & & Availability of certified doctors/midwives & 1 \\
\hline Health insurance & 1.00 & The level of BPJS participation in the community & 1 \\
\hline
\end{tabular}


The health index value is obtained by summing the results of calculating the indicators and their constituents. This formula can be explained as follows:

$\mathrm{IDZ}=0.41(\mathrm{Xl})+0.36(\mathrm{X} 2)+0.23(\mathrm{X} 3)$

$\mathrm{IDZ}=0.41(1)+0.36(0.75)+0.23(1)$

IDZ $=0.91$

The result of the IDZ calculation on the Health dimension was 0.89 in the Good category. It is supported by the house's good condition (permanent), access to clean water for toilets and drinking water, ownership of bathrooms and lavatories.

\section{Dimensions of Education}

IDZ calculation show this dimension gives a portion with the value of 0.20 . The Education index value calculation result is 0.88 . This finding means the value in the outstanding category.

The index value was obtained from analyses of the constituent variables and indicators. The calculation used the following formula.

$\mathrm{IDZ}=0.50(\mathrm{Xl})+0.50(\mathrm{X} 2)$

$\mathrm{IDZ}=0.50(0.76)+0.50(1)$

IDZ $=0.88$

Table 6. Value of Educational Variable Index of Keluarahan Curug

\begin{tabular}{|c|c|c|c|}
\hline Variable & $\begin{array}{l}\text { Value } \\
\text { Variable }\end{array}$ & Indicator & $\begin{array}{l}\text { Value } \\
\text { Indikator }\end{array}$ \\
\hline \multirow{2}{*}{$\begin{array}{l}\text { Education and literacy } \\
\text { levels }\end{array}$} & \multirow{2}{*}{0.76} & The education level of the villagers & 0.5 \\
\hline & & People can read and count & 1 \\
\hline \multirow[t]{3}{*}{ educational Facilities } & \multirow{3}{*}{1.00} & $\begin{array}{l}\text { Learning facilities and infrastructure are } \\
\text { available }\end{array}$ & 1 \\
\hline & & Access to schools is affordable and easy & 1 \\
\hline & & Availability of an adequate number of teachers & 1 \\
\hline
\end{tabular}

Source: Primary data (2019) proceed.

\section{Dimension of Humanity}

The weighted value of the Humanity dimension index is 0.17 , with a proportion of 0.17 of the total IDZ calculation. The formula used to measure these dimensions was as follows:

$\mathrm{IDZ}=0.36(\mathrm{Xl})+0.43(\mathrm{X} 2)+0.21(\mathrm{X} 3)$

$\mathrm{IDZ}=0.36(0.39)+0.43(1)+0.21(\mathrm{l})$

$\mathrm{IDZ}=0.78$

The index value for the human dimension is 0.78 (Good), so assistance is not prioritized. From the calculations carried out, the variable index and indicators in the human dimensions are as follows: 
Table 7. Index Values of Humanity Variables in Keluarahan Curug

\begin{tabular}{|c|c|c|c|}
\hline Variable & $\begin{array}{c}\text { Value } \\
\text { Variable }\end{array}$ & Indicator & $\begin{array}{c}\text { Valur } \\
\text { Indicator }\end{array}$ \\
\hline \multirow{2}{*}{$\begin{array}{l}\text { Facilities for open } \\
\text { community } \\
\text { interaction }\end{array}$} & \multirow[b]{2}{*}{0.39} & Availability of sports facilities 40:50 & 0.25 \\
\hline & & $\begin{array}{l}\text { There is a community activity group (village } \\
\text { consultative body, recitation, youth } \\
\text { organization, and arisan) }\end{array}$ & 0.5 \\
\hline \multirow{4}{*}{$\begin{array}{l}\text { Electricity, } \\
\text { communication, and } \\
\text { information } \\
\text { infrastructure }\end{array}$} & \multirow{4}{*}{1.00} & Availability of electricity & 1 \\
\hline & & There is communication access (handphone) & 1 \\
\hline & & here is internet access & 1 \\
\hline & & There are television or radio broadcasts & 1 \\
\hline $\begin{array}{l}\text { Natural disaster } \\
\text { mitigation }\end{array}$ & 1.00 & Disaster management & 1 \\
\hline
\end{tabular}

Source: Primary data (2019) proceed.

Based on the table, the index values of each variable were $0.39,1$, and 1 . In general, humanity dimensions have been fulfilled with the infrastructure that has been built. This finding makes the level of community interaction relatively high. It is outdoors or in an open field or using communication tools such as cellphones. Therefore, assistance is not prioritized based on the overall assessment of human dimensions.

\section{Dimensions of Dakwah}

The dimension of the Dakwah Index value gives a proportion of 0.22 , with a value of 0.83 . The index value is in the Very Good category, so it is less prioritized for assistance. This data shows that religious activities are in excellent condition. This success is also supported by the availability of adequate facilities for religious companions and a high level of community participation. The results of the Dakwah dimension index were obtained using the following formula:

$\mathrm{IDZ}=0.33(\mathrm{Xl})+0.30(\mathrm{X} 2)+0.37(\mathrm{X} 3)$

$\mathrm{IDZ}=0.33(1)+0.30(0.91)+0.37(0.63)$

IDZ $=0.83$

The variables index and indicators in the Dawah dimension are as follows from the calculations that have been performed.

Table 8. Value of the Dawah Variable Index of Keluarahan Curug

\begin{tabular}{|c|c|c|c|}
\hline Variable & $\begin{array}{l}\text { Value } \\
\text { Variable }\end{array}$ & Indicator & $\begin{array}{l}\text { Value } \\
\text { Indicator }\end{array}$ \\
\hline \multirow{3}{*}{$\begin{array}{l}\text { Availability of Facilities } \\
\text { and Religious Assistance }\end{array}$} & \multirow{3}{*}{1.00} & The availability of mosques in the community & 1 \\
\hline & & Access to the Mosque & 1 \\
\hline & & $\begin{array}{l}\text { There is a religious companion } \\
\text { (ustadz/ustadzah) }\end{array}$ & 1 \\
\hline \multirow{2}{*}{$\begin{array}{l}\text { Level of Public Religion } \\
\text { Knowledge }\end{array}$} & \multirow[b]{2}{*}{0.91} & The story of community Al-Quran literacy & 0.75 \\
\hline & & $\begin{array}{l}\text { Public awareness for zakat and infaq (sharing } \\
\text { with fellow humans) }\end{array}$ & 1 \\
\hline \multirow{3}{*}{$\begin{array}{l}\text { Level of Religious } \\
\text { Activity and Community } \\
\text { Participation }\end{array}$} & \multirow{3}{*}{0.63} & $\begin{array}{l}\text { The implementation of routine religious } \\
\text { activities }\end{array}$ & 1 \\
\hline & & $\begin{array}{l}\text { The level of community participation for prayer } \\
\text { five times in congregation }\end{array}$ & 0.25 \\
\hline & & $\begin{array}{l}\text { Level of community participation in routine } \\
\text { religious activities (weekly or monthly } \\
\text { recitation) }\end{array}$ & 0.75 \\
\hline
\end{tabular}

Source: Primary data (2019) proceed. 
Based on the overall assessment of the Dakwah dimension, it was in the good Enough category.

\section{Conclusion}

Measuring the IDZ value of Kelurahan Curug, Bojongsari Subdistrict, Depok City, is 0.79 in categorical good to conclude that it is not considered assisted. There are three dimensions: economic dimension (0.61), humanity dimension (0.81), and dakwah dimension (0.83). Meanwhile, two other dimensions, namely: education and health dimensions, obtained index scores of 0.88 and 0.91, which were considered exemplary and were not prioritized for assistance. Even so, there are indicators that require assistance in each dimension.

As a living document with limited space and time, the IDZ can be updated and adapted to the context of changes, especially in the development of zakat fund management in the future. Therefore, IDZ measurements can be carried out again to obtain an overview of the development of the Kelurahan Curug. This finding will make it easier for zakat distribution so that the impact and changes will be more felt and on the target. 


\section{References}

Ahmed, H. (2004). Role of Zakah and Awqaf in Poverty Alleviation. In Islamic Research and Training Institute.

Ahmed, H. (2008). Zakah, Macroeconomic Policies, and Poverty Alleviation: Lessons from Simulations on Bangladesh. Thoughts on Economics, 18(3), 81-105.

Akbarizan, Marizal, M., Soleh, M., Hertina, A, M. A., Yendra, R., \& Fudholi, A. (2016). Utilization of Holt's Forecasting Model for Zakat Collection in Indonesia. American Journal of Applied Science, 13(12), 1342-1346. https://doi.org/10.3844/ajassp.2016.1342.1346

Bahri, E. S., Aslam, M. M. A., Hj Hasan, A. A., \& Wibowo, H. (2019). Maqasid Al-Shariah in Micro-entrepreneurs Development: an Overview. International Conference of Zakat, 258267. https://doi.org/10.37706/iconz.2019.182

Bahri, E. S., \& Khumaini, S. (2020). Analisis Efektivitas Penyaluran Zakat pada Badan Amil Zakat Nasional. Al Maal: Journal of Islamic Economics and Banking, 1(2). https://doi.org/10.31000/almaal.vli2.1878

Beik, I. S., \& Sartono, B. (2019). Proposing a Zakat Empowerment Program Using IDZ: Case from Cemplang Village, Bogor, Indonesia. International Journal of Zakat Vol., 4(131), 45-54.

Daly, S., \& Frikha, M. (2015). Islamic Finance in Favor to Development and Economic Growth: An Illustration of the Principle of "Zakat." Arabian Journal of Business and Management Review, 5(5). https://doi.org/10.4172/2223-5833.1000145

Hakim, F. N., Mahri, A. J. W., \& Nurasyiah, A. (2019). Implementation of Zakat Village Index (Survey in Binangun Village, Pataruman Sub District, Banjar City). KnE Social Sciences, 3(13), 809. https://doi.org/10.18502/kss.v3il3.4249

Jamil, A. (2018). Implementasi Indeks Desa Zakat pada Desa Sungai Dua Kecamatan Rambutan (untuk Desa yang Terukur dan Berkelanjutan). KHOZANA: Jurnal Ekonomi Dan Perbankan Islam, 1(2), 245-257.

Jamilah, S. (2017). c. Ikhraith-Humaniora, 1(2), 45-52.

Kasri, R. A. (2016). Maqasid al-Shariah and Performance of Zakah Institutions. Kyoto Bulletin of Islamic Area Studies, 9(March), 19-41.

Ladiku, H. (2020). Analisis Epistimologi Zakat dalam Perspektif Fiqih. Jurnal Ilmiah ALJauhari: Jurnal Studi Islam Dan Interdisipliner, 5(1), 1-22.

Lailatussufiani, S., Burhan, M. U., \& Multifiah. (2016). The Utilization of Zakat, Infaq, and Sadaqah for Community Empowerment ( Case Study of BAZNAS West Nusa Tenggara Province ). International Journal of Business and Management Invention, 5(10), 152-160.

Lenap, I. P., Sasanti, E. E., Karim, N. K., \& Sari, N. K. (2020). Zakat Disbursement Efficiency Based on Zakat Core Principles in Managing Zakat Funds in Baznas of West Nusa Tenggara Province. Jurnal Akuntansi Dan Bisnis, 20(1), 103. https://doi.org/10.20961/jab.v20il.500

Maulida, S., \& Rahmatullah, A. (2018). Indeks Desa Zakat (IDZ) implemented for Priority Areas of the Zakat Community Development (ZCD) Program for the Empowerment of Productive Mustahiq in South Kalimantan. 3(3), 83-99.

Novianti, T., \& Ali, K. M. (2018). Implementation of the Zakat Village Index to Support a Zakat Community Development Program in Bedono Village, Demak District. 3(3), 25-38.

Nurzaman, M. S., \& Annisa, N. (2017). Implementasi Indeks Desa Zakat dalam Program 
ZCD Baznas. Iqtishodia.

Oktaviani, R., \& Bahri, E. S. (2018). Zakat Produktif Sebagai Modal Kerja Usaha Mikro.

2(October), 101-120. https://doi.org/10.21070/perisai.v2i2.1686

Puskas. (2017a). Dampak Pendayagunaan Zakat Baznas Terhadap Kesejahteraan Mustahik di Indonesia. In Puskas (Vol. 57).

Puskas. (2017b). Indeks Desa Zakat. In Puskas.

Rais, I. (2009). Muzakki dan Kriterianya Dalam Tinjauan Fikih Zakat. Al-Iqtishad: Jurnal Ilmu Ekonomi Syariah, 1(1). https://doi.org/10.15408/aiq.vlil.2456

S, A. B. (2016). Zakat sebagai Instrumen Pembangunan Ekonomi dan Kesejahteraan Ummat. Li Falah: Jurnal Studi Ekonomi Dan Bisnis Islam, I(2), 74-89. https://doi.org/10.31332/lifalah.vli2.484

Sarif, S., \& Kamri, N. 'Azzah. (2009). A Theoretical Discussion of Zakat for Income Generation and Its Fiqh Issues. Shariah Journal, 17(3), 457-500.

Satori Ismail, A., Farid Mas'udi, M., Bahri, E. S., Halim, I., Tajang, M. N., Qasim, F., Hambali, A., \& Erianton, P. (2018). Fikih Zakat Kontekstual Indonsia. BAZNAS.

Triyani, N., Beik, I. S., \& Baga, L. M. (2018). Manajemen Risiko pada Badan Amil Zakat Nasional (BAZNAS). Al-Muzara'ah, 5(2), 107-124. https://doi.org/10.29244/jam.5.2.107124

Widiastuti, T., \& Rosyidi, S. (2015). Model Pendayagunaan Zakat Produktif oleh Lembaga Zakat dalam Meningkatkan Pendapatan Mustahiq. Jurnal Ekonomi Dan Bisnis Islam, 1(1), 89-102.

Zalikha, S. (2016). Pendistribusian Zakat Produktif Dalam Perspektif Islam. Jurnal Ilmiah Islam Futura, 15(2), 304. https://doi.org/10.22373/jiif.vl5i2.547 